CASSOWARY - Volume 1(2): 133 - 139

ISSN : 2614-8900

E-ISSN : 2622-6545

CProgram Pascasarjana Universitas Papua, https://pasca.unipa.ac.id/

\title{
Tanggap pertumbuhan dan hasil tomat yang di inokulasi FMA dalam pengendalian Fusarium (Fusarium oxysporum f.sp. lycopersici)
}

\author{
Response to growth and yield of tomatoes inoculated by FMA in Fusarium control \\ (Fusarium oxysporum f.sp. lycopersici)
}

\author{
Cahterine Pentury, Antonius Suparno, Eko Martanto*
}

Program Studi Magister Ilmu Pertanian, PPs Universitas Papua

Jalan Gunung Salju Amban, Manokwari, kodepos 98314, Papua Barat, Indonesia

*Email:

\begin{abstract}
The Wilt in tomato plants is caused by Fusarium oxysporum sp. Lycopersici. Fusarium oxysporum is soil borne which causes considerable losses. FMA as a biological agent provides an alternative opportunity to control root diseases such as fusarium. The purpose of this study was to study the treatment of FMA inoculation which is appropriate while controlling the damage of tomato plants caused by fusarium. The research design used was the experimental method in Completely Randomized Design. The results showed that the treatment of mycorrhizae inoculated one week before planting and continued with fusarium inoculation at the time of planting showed good results in inducing the resistance of tomato plants to fusarium disease. This is evidenced by root colonization in tomato plants by $53 \%$ and the average intensity of attacks by $3.14 \%$. The mycorrhizal treatment inoculated one week before planting and followed by fusarium inoculation at planting also showed good results in increasing the growth of tomato plants compared to other treatments applied by mycorrhiza.
\end{abstract}

Keywords: fusarium, inokulan, mikoriza, pengendalian, tomat

ABSTRAK: Penyakit layu pada tanaman tomat disebabkan oleh fungi Fusarium oxysporum f. sp. Lycopersici. Fusarium oxysporum adalah fungi tular tanah (soil borne) yang menyebabkan kerugian cukup besar. FMA sebagai agens hayati memberikan peluang alternatife dalam pengendalian penyakit akar seperti fusarium. Tujuan dari penelitian ini adalah untuk mempelajari perlakuan inokulasi FMA yang tepat sekaligus dapat mengendalikan kerusakan tanaman tomat yang diakibatkan oleh fusarium. Rancangan penelitian yang digunakan adalah metode eksperimen dalam Rancangan Acak Lengkap. Hasil penelitian menyatakan bahwa perlakuan mikoriza yang diinokulasi satu minggu sebelum tanam dan dilanjutkan dengan inokulasi fusarium pada saat tanam menunjukan hasil yang baik dalam menginduksi ketahanan tanaman tomat terhadap penyakit fusarium. Hal ini dibuktikan dengan kolonisasi akar pada tanaman tomat sebesar $53 \%$ dan rata-rata intensitas serangan sebesar $3,14 \%$. Perlakuan mikoriza yang di inokulasi satu minggu sebelum tanam dan dilanjutkan dengan inokulasi fusarium pada saat tanam juga menunjukan hasil yang baik dalam meningkatkan pertumbuhan tanaman tomat dibandingka dengan perlakuan lain yang diaplikasi mikoriza.

Kata kunci : fusarium, inokulan, mikoriza, pengendalian, tomat 


\section{PENDAHULUAN}

Penyakit layu pada tanaman tomat disebabkan oleh fungi Fusarium oxysporum f. sp. Lycopersici. Fusarium oxysporum adalah fungi tular tanah (soil borne) yang menyebabkan kerugian cukup besar. Kerugian pra panen yang diakibatkan oleh fungi pada pertanian di seluruh dunia mencapai $12 \%$ dan jumlahnya jauh lebih tinggi di negaranegara berkembang (Kim et al., 2003 dalam Kabirun, 2011). Di Lembang dan Pacet, Jawa Barat intensitas penyakit yang disebabkan oleh fungi mencapai 16,7\%, sedang di Malang, Jawa Timur 10,25\% (Semangun, 1996 dalam Djaya, 2003). Di Kalimantan Tengah khususnya di kota Palangkaraya, berdasarkan hasil penga-matan keliling dan pengamatan petak tetap, intensitas serangan layu fusarium berkisar 25\% - 50\% (Balai Pengkajian Teknologi Pertanian Kalimantan Tengah, 1997 dalam Djaya, 2003).

Fusarium oxysporum dapat bertahan lama dalam tanah. Tanah yang sudah terinfestasi akan sukar dibebaskan kembali dari fungi ini oleh karena itu tanaman yang rentan mudah terinfeksi fusarium. Fungi akan menginfeksi akar melalui luka, kemudian akan menetap dan berkembang di berkas pembuluh (Semangun, 2006).

Fungi mikoriza arbuscular (FMA) merupakan fungi yang bersimbiosis dengan akar tanaman dan tentunya berfungsi membantu tanaman dalam penyerapan unsur hara dan meningkatkan ketahanan tanaman terhadap serangan pathogen akar.

Inokulasi FMA diharapkan dapat menekan atau menghilangkan infeksi fusarium. Namun demikian, kehandalan FMA dalam mengendalikan fusarium diduga ditentukan oleh simbion. Tujuan dari penelitian ini adalah untuk mempelajari perlakuan inokulasi FMA yang tepat sekaligus dapat mengendalikan kerusakan tanaman tomat yang diakibatkan oleh fusarium.

\section{BAHAN DAN METODE}

Penelitian disusun dengan metode eksperimen dalam Rancangan Acak Lengkap menggunakan perlakuan selang waktu inokulasi FMA dan fusarium yang meliputi Kontrol = tanpa inokulasi FMA dan Fusarium, $\mathrm{M}=$ hanya diinokulasi FMA saat tanam, $\mathrm{F}=$ hanya diinokulasi fusarium saat tanam, $\mathrm{FM}=$ di inokulasi fusarium 1 minggu sebelum tanam, dilanjutkan dengan pemberian FMA saat tanam, MF = di inokulasi FMA 1 minggu sebelum tanam, dilanjutkan dengan pemberian fusarium saat tanam dan $\mathrm{M}+\mathrm{F}=$ di inokulasi FMA dan fusarium bersamaan pada saat tanam.

Persiapan bibit dilakukan dengan prosedur sebagai berikut tanah sebagai media tanam yang diambil dari kampung Ayambori dikering anginkan selama tiga hari. Koker diisi dengan tanah dan tanam $2-3$ bibit tomat varietas Lentana untuk setiap koker. Selanjutnya diatur pada rak-rak. Bibit disiram dengan air mengalir secukupnya. Pemeliharaan dilakukan hingga satu minggu selanjutnya tanaman tomat dipindahkan ke dalam polibag $5 \mathrm{~kg}$ sesuai dengan perlakuan yang ada Fusarium diisolasi dari tanaman tomat yang terserang gejala busuk akar oleh fusarium. Bagian tanaman yang sakit dipotong kecil-kecil ukuran 1 $\mathrm{x} 1 \mathrm{~cm}^{2}$ dan di masukan dalam larutan klorox 1\% selama $1-2$ menit. Kemudian bagian tanaman tersebut di masukan dalam air steril selama $1-2$ menit dan di kering anginkan di atas kertas saring steril. Tanaman diisolasi pada permukaan media PDA dan di simpan pada suhu ruang.

Perbanyakan FMA dilakukan dengan, pot plastik diisi setengah bagian dengan zeolit. Letakan sekitar $50 \mathrm{~g}$ Mycofer kebagian atas zeolit dan kemudian taburkan zeolite lagi pada permu- 
kaan Mycofer tersebut. Tanam 2-3 benih sorgum untuk setiap pot, akar tanaman harus mengenai permukaan Mycofer dalam pot plastik. Pot plastik dan selanjutnya diatur pada arak-rak perbanyakan. Inokulan di siram dengan larutan hiponex merah $(1$ gr per $2 \mathrm{~L}$ air) dan dilakukan pemupukan dua kali seminggu. Pemupukan juga dapat dilakukan hanya satu kali seminggu namun dosis pupuknya diubah menjadi $1 \mathrm{~g}$ per $1 \mathrm{~L}$ air. Penyiraman air dilakukan di antara periode pemupukan, namun sebaiknya dilakukan sehemat mungkin karena sporulasi FMA terpacu oleh kondisi yang kering. Pemeliharaan dilakuakan hingga umur 3 (tiga) bulan. Pemanenan Mycofer dilakukan setelah perbanyakan dan dilakukan stressing pada akhir masa perbanyakan. Stressing dilakukan dengan cara mengurangi volume penyiraman sehingga perlahan-lahan tanaman inang mati.

Inokulasi Fusarium dan FMA dilakukan sebagai berikut tanah yang diambil dari kampung Ayambori sebagai media tanam dikering anginkan selama 3 hari dan dimasukan dalam polibag sebanyak $5 \mathrm{~kg}$. Semai bibit dalam koker selama satu minggu. Lakukan Inokulasi FMA sebanyak $10 \mathrm{~g}$ dalam beberapa polibag dan inokulasi fusarium sebanyak $10 \mathrm{~g}$ dalam beberapa polibag lainnya selama satu minggu dan selanjutnya tambahkan inokulasi FMA sebanyak 10 $\mathrm{g}$ dalam polibag yang berisi tanah yang sudah diinokulasi fusarium satu minggu sebelumnya dan bibit ditanam. Tambahkan juga inokulasi fusarium sebanyak $10 \mathrm{~g}$ dalam polibag yang berisi tanah yang sudah diinokulasi FMA satu minggu sebelumnya dan bibit ditanam. Polibag selanjutnya diatur pada rak-rak. Penyiraman air yang dilakukan satu kali sehari. Pemeliharaan dan pengamatan dilakukan setiap minggu hingga tanaman berumur empat bulan. Selanjutnya penen dilakukan setelah tanaman berproduksi.
Peubah yang diamati ialah intensitas spenyakit (\%) yang diukur menggunakan rumus:

$$
\mathrm{I}=100 \% \times \mathrm{a} /(\mathrm{a}+\mathrm{b})
$$

Keterangan:

I = Intensitas serangan penyakit,

$\mathrm{a}=$ Jumlah tanaman yang terserang / mati,

$\mathrm{b}=$ Jumlah tanaman yang sehat.

Tinggi tanaman $(\mathrm{cm})$ diukur dari permukaan tanah hingga pada daun tertinggi atau tunas tertinggi pada umur 2,4,6,8 dan 10 MST, Jumlah cabang per tanaman dihitung pada saat panen yaitu dengan menghitung jumlah cabang yang terbentuk selama pertumbuhan tomat, jumlah buah per tanaman (buah) dihitung pada saat panen meliputi buah yang normal dan buah yang abnormal, jumlah bunga pertanaman, bobot kering batang (gr), bobot kering akar (gr), kolonisasi FMA (\%) pada akhir pengamatan. Perhitungan persentase kolonisasi akar menggunakan metode Panjang akar terkolonisasi Giovannetti dan Mosse dalam Susan (1996).

\section{HASIL DAN PEMBAHASAN}

Hasil penelitian menunjukan bahwa mikoriza dapat mempengaruhi pertumbuhan dan hasil tomat yang terinfeksi fusarium (Tabel 1).

Tabel 1. Jumlah bunga, tinggi tanaman, jumlah cabang dan jumlah buah akibat inokulasi FMA dalam pengendalian fusarium pada tomat 


\begin{tabular}{|c|c|c|c|c|}
\hline $\begin{array}{l}\text { Perla } \\
\text { kuan }\end{array}$ & JB & TT & $\mathrm{JC}$ & $\mathbf{J B u}$ \\
\hline $\mathbf{O}$ & $\begin{array}{c}0,07 \\
\text { bc }\end{array}$ & $\begin{array}{c}36,70 \\
\mathrm{c}\end{array}$ & $8,42 \mathrm{ab}$ & $\begin{array}{c}0,07 \\
\text { bc }\end{array}$ \\
\hline M & $\begin{array}{c}0,35 \\
\mathrm{a}\end{array}$ & $\begin{array}{c}54,42 \\
\mathrm{a}\end{array}$ & $10,10 \mathrm{a}$ & $\begin{array}{c}0,35 \\
\mathrm{a}\end{array}$ \\
\hline $\mathbf{F}$ & $\begin{array}{c}0,05 \\
\mathrm{c}\end{array}$ & $\begin{array}{c}33,00 \\
\mathrm{c}\end{array}$ & $8,12 \mathrm{~b}$ & $\begin{array}{c}0,02 \\
\mathrm{c}\end{array}$ \\
\hline MF & $\begin{array}{l}0,17 \\
\text { abc }\end{array}$ & $\begin{array}{c}51,30 \\
\text { ab }\end{array}$ & $10,07 \mathrm{a}$ & $\begin{array}{c}0,10 \\
\text { bc }\end{array}$ \\
\hline FM & $\begin{array}{c}0,32 \\
\mathrm{ab}\end{array}$ & $\begin{array}{c}37,47 \\
\mathrm{c}\end{array}$ & $8,50 \mathrm{ab}$ & $\begin{array}{c}0,27 \\
\text { ab }\end{array}$ \\
\hline $\mathbf{M}+\mathbf{F}$ & $\begin{array}{l}0,15 \\
\text { abc }\end{array}$ & $\begin{array}{c}38,45 \\
\text { bc }\end{array}$ & $8,82 \mathrm{ab}$ & $\begin{array}{c}0,10 \\
\text { bc }\end{array}$ \\
\hline $\begin{array}{l}\text { Nilai } \\
\text { LSD } \\
\mathbf{5 \%}\end{array}$ & 0,25 & 13,64 & 1,88 & 0,21 \\
\hline
\end{tabular}

Catatan: Angka yang diikuti huruf yang sama pada kolom yang sama tidak berbeda nyata menurut uji lanjut LSD pada taraf 5\%

Keterangan :

$\mathrm{O}=$ Kontrol,

$\mathrm{M}=$ Perlakuan mikoriza,

$\mathrm{F}=$ Perlakuan fusarium,

$\mathrm{MF}=$ Mikoriza diaplikasikan 1 minggu + Fusarium,

$\mathrm{FM}=$ Fusarium diaplikasikan 1 minggu + mikoriza,

$\mathrm{M}+\mathrm{F}=$ mikoriza + fusarium,

$\mathrm{JB}=$ Jumlah bunga,

TT = Tinggi tanaman,

$\mathrm{JC}=$ Jumlah cabang,

$\mathrm{JBu}=\mathrm{Jumlah}$ buah

Inokulasi FMA dalam pengendalian fusarium tidak berbeda nyata pada variabel pertumbuhan jumlah bunga dan jumlah cabang tetapi pada variable tinggi tanaman dan jumlah buah menunjukkan hasil berbeda nyata. Hal ini menunjukan bahwa tanaman tomat memberikan reaksi pertumbuhan yang positif walaupun tanaman tomat terinfeksi patogen fusarium. Selain tanaman tomat menunjukkan reaksi positif, FMA juga dapat menjalankan fungsi dan perannya dengan baik. Mikoriza yang menginfeksi akar tanaman tomat telah memasuki masa aktif dan berinteraksi mutualisme dengan Bobot kering Perlakuan tanaman. Hifa eksternal mikoriza telah keluar dan menurut Talanca (2010), akar yang telah bermikoriza dapat menyerap $\mathrm{P}$ dari larutan tanah pada konsentrasi dimana akar tanaman mempunyai metabolism energi lebih besar sehingga aktif dalam pengambilan $\mathrm{P}$. Unsur hara $\mathrm{N}$ juga diduga ikut diserap mikoriza untuk tanaman, karena menurut Indrianti et al. (2013), unsur hara berupa $\mathrm{N}$ berfungsi untuk merangsang pertumbuhan tanaman.

Tabel 2 menunjukan bahwa perlakuan mikoriza terhadap bobot kering batang tanaman tomat menunjukan hasil yang berbeda nyata. Rata-rata berat kering batang tertinggi diperoleh perlakuan mikoriza sebesar 0,53 gram dan rata-rata berat kering batang terendah adalah perlakuan fusarium sebesar 0,05 gram.

Tabel 2. Hasil uji lanjut pengaruh FMA terhadap bobot berat kering batang tanaman tomat

\begin{tabular}{|c|c|c|}
\hline Perlakuan & Rata-Rata & $\begin{array}{c}\text { Berbeda / } \\
\text { Tidak } \\
\text { berbeda }\end{array}$ \\
\hline M & 0,53 & a \\
\hline MF & 0,33 & b \\
\hline FM & 0,20 & $\mathrm{c}$ \\
\hline M+F & 0,13 & cd \\
\hline O & 0,11 & cd \\
\hline F & 0,05 & $\mathrm{~d}$ \\
\hline
\end{tabular}

Berat kering tanaman merupakan indikasi keberhasilan pertumbuhan tanaman karena berat kering tanaman merupakan petunjuk adanya kandungan protein dan organik lainnya yang merupakan hasil fotosintesis yang dapat diendapkan setelah kadar air dikeringkan. Semakin besar berat kering tanaman menunjukan semakin efisien proses fotosintesis yang terjadi dan produktivitas serta perkembangan sel jaringan semakin tinggi dan cepat, sehingga pertumbuhan tanaman menjadi lebih 
baik, yang akhirnya berat kering tanaman meningkat.

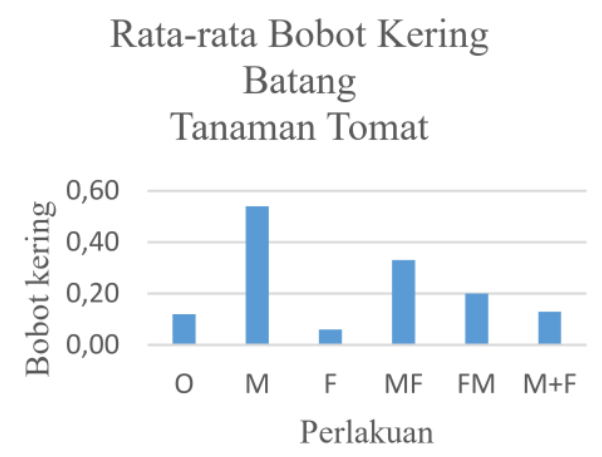

Gambar 1. Rata-rata bobot berat kering batang tanaman tomat

\section{Rata-rata Bobot Kering Akar \\ Tanaman Tomat}

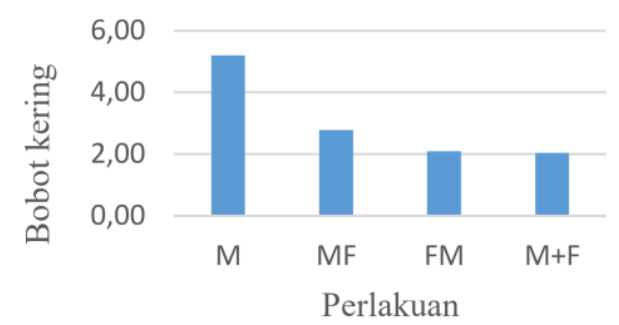

Gambar 2. Rata-rata bobot kering akar tanaman tomat

Gambar 1 dan 2 menunjukan bahwa mikoriza mampu beradaptasi pada tanaman yang tercekam oleh faktor biotik seperti serangan patogen. Menurut Suharti et al. (2011), bahwa mikoriza memiliki mekanisme dalam mengendalikan berbagai jenis pathogen yang dapat terjadi secara langsung berupa kompetisi dan antibiosis. Selanjutnya, ditambahkan bahwa penyebabnya adalah partumbuhan propagul infektif dari mikoriza dapat menghalangi patogen untuk memasuki akar tanaman. Secara tidak langsung, melalui proses respon fisiologis dan biokimia dengan terjadinya perubahan aktivitas enzim dan peningkatan senyawa kimia yang menghambat perkembangan patogen.
Pada gambar 3 menggambarkan hasil intensitas serangan penyakit dari semua perlakuan pada tanaman. Jika dibandingkan antara perlakuan bahwa Mikoriza yang diaplikasikan 1 minggu sebelum Fusarium sp. Memberikan pengaruh yang baik dalam meningkatkan

ketahanan tanaman karena intensitas penyakit yang dihasilkan rendah dibandingkan dengan perlakuan Fusarium sp. diaplikasikan 1 minggu sebelum mikoriza. Hasil intenitas serangan penyakit menjelaskan perbandingan antara perlakuan mikoriza bahwa semakin besar intensitas penyakit, maka perlakuan mikoriza yang diberikan pada tanaman keefektifan ketahanannya terhadap tanaman tomat rendah dan begitu juga sebaliknya.

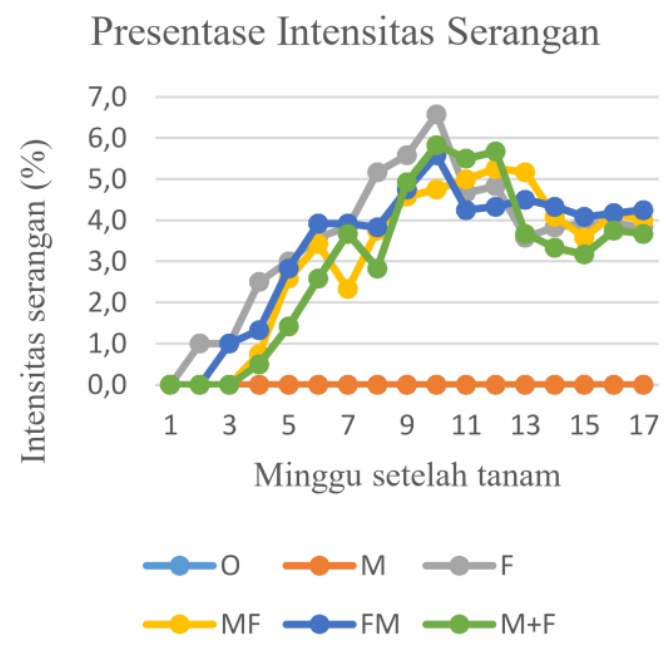

Gambar 3. Presentase intensitas serangan

Hasil ini didukung oleh pernyataan Talanca (2010), bahwa fungi mikoriza dapat bersimbiose dengan akar tanaman inang, dan mempunyai pengaruh yang luas terhadap mikroorganisme yang bersifat patogen. Akar tanaman inang yang terinfeksi mikoriza mempunyai eksudat akar yang berbeda dengan eksudat akar yang tidak bermikoriza dan akar tanaman yang tidak terserang pato- 
gen. Perubahan eksudat akar tanaman inang ini mempengaruhi perubahan dalam rhizofer yang mengakibatkan meningkatnya ketahanan dari serangan patogen. Ketahanan ini lebih meningkat karena adanya produksi antibiotik dari mikoriza. Hasil pengamatan yang dilakukan pada akar tanaman tomat yang diinokulasi mikoriza menunjukan adanya hifa, vesikel dan spora didalam akar tanaman (Gambar 4) yang diamati melalui pengamatan mikroskopis dengan menggunakan teknik pewarnaan akar yang menunjukan adanya tanda infeksi mikoriza. Metode yang digunakan untuk pembersihan dan pewarnaan akar adalah metode dari Kormanik dan Mc Graw (1982) dalam Susan (1996).

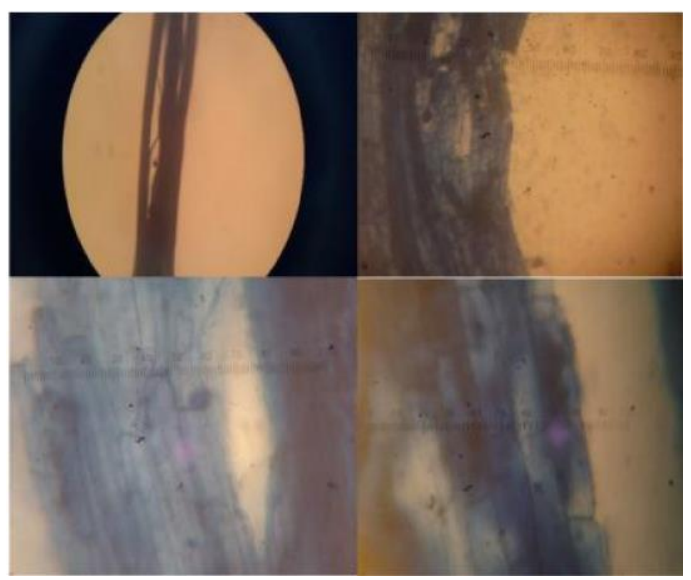

Gambar 4. Fungi mikoriza yang mengkolonisasi jaringan akar tanaman tomat

Infeksi mikoriza tertinggi terdapat pada perlakuan yang hanya diinokulasi mikoriza saja dengan tingkat kolonisasi akar tanaman mencapai $73 \%$ dan infeksi mikoriza terendah pada perlakuan Fusarium sp. diaplikasikan 1 minggu sebelum mikoriza sebesar $31 \%$. Pada gambar 5 menunjukkan adanya hubungan korelasi antar intensitas serangan penyakit layu fusarium dengan kolonisasi akar oleh FMA. Hal ini menunjukkan bahwa semakin tinggi persentase kolonisasi akar oleh FMA, maka semakin kecil persentase intensitas serangan.

Mikoriza menggunakan semua kelebihan karbohidrat dan eksudat akar tanaman, sehingga tercipta lingkungan yang tidak cocok bagi patogen. Di lain pihak, fungi mikoriza ada yang dapat memproduksi antibiotik yang dapat mematikan patogen. Jika terhadap jasad renik berguna, FMA memberikan sumbangan yang menguntungkan, sebaliknya terhadap jasad renik penyebab penyakit FMA justru berperan sebagai pengendali hayati yang aktif terutama terhadap serangan pathogen akar (Oktavitani, 2009). Interaksi sebenarnya antara FMA, patogen akar, dan inang cukup kompleks dan kemampuan FMA dalam melindungi tanaman terhadap serangan patogen bergantung pada spesies, atau strain fungi FMA dan tanaman yang terserang.

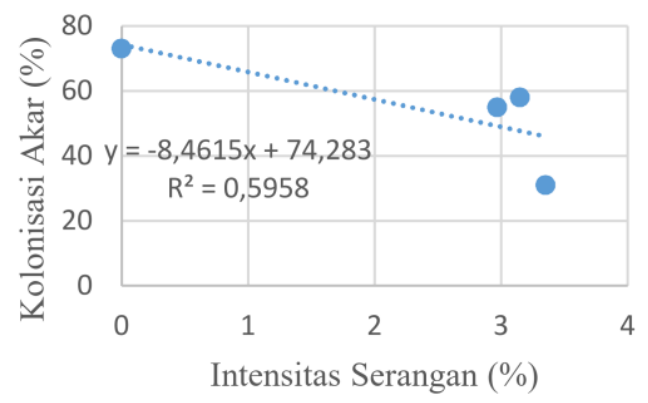

Gambar 5. Hubungan intensitas serangan penyakit dengan kolonisasi akar oleh FMA

\section{KESIMPULAN}

Dari hasil penelitian ini dapat disimpulkan bahwa :

1. Mikoriza yang diinokulasi satu minggu sebelum tanam dan dilanjutkan dengan inokulasi fusarium pada saat tanam menunjukkan hasil yang baik dalam menginduksi ketahanan tanaman tomat terhadap penyakit fusarium. Hal ini dibuktikan dengan kolonisasi akar pada 
tanaman tomat sebesar $53 \%$ dan ratarata intensitas serangan sebesar $3,14 \%$.

2. Mikoriza yang diinokulasi satu minggu sebelum tanam dan dilanjutkan dengan inokulasi fusarium pada saat tanam juga menunjukkan hasil yang baik dalam meningkatkan pertumbuhan tinggi tanaman $(103,83 \mathrm{~cm})$, bobot kering batang $(0,53$ gr $)$ dan bobot kering akar $(5,20$ gr $)$ dibandingkan dengan perlakuan lain yang diaplikasi mikoriza.

3. Semakin tinggi kolonisasi FMA, maka intensitas penyakit semakin rendah $(r=0,77)$

\section{DAFTAR PUSTAKA}

Agus Djaya A, R.B. Mulya, Giyanto, Marsiah. 2003. Uji Keefektifan Mikroorganisme Antagonis dan Bahan Organik terhadap Penyakit Layu Fusarium (Fusarium oxysporum) pada Tanaman Tomat. Didalam Peranan Fitopatologi dalam Menumbuh kembangkan Desentralisasi Agribisnis Berkelanjutan pada Era Persaingan Pasar Bebas. Prosiding Kongres XVII dan Seminar Ilmiah Nasional Bandung, 06 Agustus 2003. Perhimpunan Fitopatologi Indonesia. 61-70.

Indriati, G., L.I. Ningsih, dan Rizki. 2013. Pengaruh pemberian fungi mikoriza multispora terhadap produksi tanaman jagung (Zea mays L.). Hal. 323-327. Pros. Semirata FMIPA Universitas Lampung, 2013

Kabirun, S. 2011. Mikoriza. http://id. wikipedia.org/wiki/Mikoriza. [25 September 2011]

Kabirun, S. 2011. Tomat. http://id.wiki pedia.org/wiki/Tomat. [10 Okto ber 2011]

Kaminskyj, Susan, G.W. 1996. Effective and flexible methods for visualizing dan quantifying endorhizal fungi. Department Of Biology, University of Saskatchewan. 112 Science Place. Saskatoon SK, Canada. S7N 5E2

Semangun, H. 2006. Pengantar Ilmu Penyakit Tumbuhan. Jogjakarta. Gajah Mada University Press

Suharti, N., T. Habazar, N. Nasir, Dachryanus, dan Jamsari. 2011. Induksi ketahanan tanaman jahe terhadap penyakit layu Ralstonia solanacearum ras 4. Menggunakan fungi mikoriza arbuskular (FMA) indigenus. Jurnal HPT Tropika 11(1):102-111.

Talanca, H. 2010. Status cendawan mikoriza vesicular - arbuscular (MVA) pada tanaman. Pros. Pekan Serealia Nasional, 2010. Hal:353-357 
CASSOWARY - Volume 1(2): 133 - 139 